\title{
Un hombre, solo...
}

\author{
JORGE JIMÉNEZ
}

(Traductor y Editor)

Un hombre, solo, camina a la orilla del mar. Llueve. Como casi siempre en esos parajes acostumbrados a la mirada del paseante que, al amparo de un paraguas, avanza por la arena. Diríase que su paso, inadecuadamente rápido para el terreno que pisa, añora la firmeza del cemento, del asfalto o de cualquier otro pavimento que le permitiera obtener mejor rendimiento de su esfuerzo muscular.

Huye. Disimuladamente, pero huye. ¿De qué?, ¿de quién?

De momento, sólo nos es dado saber su oficio. Es, no cabe duda, un escritor. Esta afirmación puede parecer excesivamente rotunda, sobre todo si se tiene en cuenta la infinidad de profesiones que pueden atribuirse a un hombre que camina solo bajo la lluvia a orillas del mar.

La aseveración, sin embargo, no es gratuita. Está, por una parte, el hecho de que yo sé que, en efecto, se trata de un escritor, pero este pequeño detalle carece de importancia comparado con una certeza que -ésta sí- está al alcance de cualquier observador medianamente perspicaz: sólo el oficio de escritor es capaz de llevar a una persona a semejante huida disfrazada de paseo crepuscular bajo el aguacero. Nadie, salvo un suicida camino del lugar elegido para su autoinmolación, podría mostrar semejante desprecio por el pausado ritmo que la playa parece imponer a 30 paseantes. A decir verdad, son más los rasgos que asimilan a nuestro personaje con un suicida: la mirada ensimismada; los labios, contraídos en una mueca a medio camino entre la ira y el desdén; los dedos de la mano libre parecen afanados en reconocerse unos a otros por medio de un continuo frote...

Sí, también podría ser un suicida, pero ¿qué suicida se molestaría en cobijarse bajo un paraguas camino de su cita con la solución final?

Pero sé aún más sobre ese desasosegado paseante. Conozco, por ejemplo, el motivo de su desazón. En efecto, sobre el asiento trasero de mi coche 
descansa el mazo de folios repletos de anotaciones que el escritor ahora en fuga me acaba de entregar minutos antes. Junto a ellos, un libro que el escritor me ha regalado al principio de nuestra entrevista: Errata, de George Steiner. El libro viene subrayado, concretamente en su página 37: "Ya sea prosaica o sublime, rutinaria o creadora, una traducción es en todo momento una sacudida de comprensión primaria. El traductor es (...) un espejo que se mira en otro y que intercambia la máxima cantidad de luz posible".

A medida que ia autopista me aleja del lugar de mi cita con el escritor, comprendo mejor el recado que trataba de enviarme a través de Steiner: debo ajustar mi espejo de traductor al suyo de autor. La luz que la primera versión de mi traducción intercambia con el original de su obra debe -mitigando el brillo aquí, enriqueciendo allá la gama de color- adecuarse a su esfuerzo de creador por abarcar una paleta de tonos inédita.

También comprendo, sin embargo, que el escritor, a lo largo de nuestra larga conversación sobre la traducción de su obra, ha experimentado una dolorosa sensación: se ve obligado a aceptar como huésped de su campamento literario a un intruso con ideas propias. El intruso está de paso, cierto, y en ningún momento le discutirá la propiedad del predio, pero, paradójicamente, su sola presencia constituye cierta reivindicación de autoría sobre la obra traducida. Esa reivindicación pasaría prácticamente desapercibida si el autor desconociera o no dominara en profundidad la lengua de destino de la traducción. Pero no es éste el caso, y de ahí surge la desazón que acaba de llevar a nuestro escritor a su desasosegada caminata vespertina.

Aunque podía haberlo hecho de otra forma, el escritor encomendó la traducción de su obra a alguien de su confianza, y, puesto que podía elegir, optó por una persona que le asegurara, además de los mínimos técnicos exigibles, una comunicación fluida a la hora de contrastar los puntos de vista sobre los posibles problemas que la traslación planteara.

Ahora, sin embargo, el escritor se encuentra en una difícil tesitura: debe reflexionar de nuevo sobre su obra, pero, en esta ocasión, a la luz de un candil bien diferente del que en su día iluminara su arduo camino a través de la tierra ignota de la creación.

Así, significados y significantes sufren un proceso de recolocación, dislocación, degeneración y regeneración ante los atónitos ojos del autor. Lo que se preveía fácil tránsito entre dos melodías básicamente conocidas, acusa la intervención de una voz con matices y adherencias propios y, en ocasiones, cierta o aparentemente distantes de la intencionalidad primigenia plasmada en el pentagrama original.

En suma: el escritor ha sido colocado al borde del precipicio de la deconstrucción, cuando esperaba reposar en la plácida playa de la decodificación (espero se me toleren los dos más que probables galicismos).

Las anotaciones que, de su ira y letra, ha garabateado a los márgenes de la traducción parecen, a primera vista, apuntes subjetivos sobre determinados 
problemas técnicos: cacofonías, opciones léxicas dudosas, ilaciones falsas, debilidades o exageraciones expresivas, gradaciones incorrectas, aposiciones mal resueltas... Y para eso son, precisamente, las primeras versiones.

Hasta aquí, todo está en orden. Nada que reprochar, y sí mucho que agradecer, al celo del escritor que se ha sumergido hasta los ojos en el texto traducido. Pero, a medida que avanzábamos en el desglose de los problemas, una realidad oculta ha emergido entre la niebla de las cuestiones puntuales: el fantasma de la reescritura, emboscado en la maraña lexicosintáctica, asoma de pronto. Su conciencia de estilo propio se rebela ante la agresión del hermanastro que habla en otra lengua.

En este punto, El escritor puede tratar de resolver su angustia de varias maneras. Si se desentendiera de la criatura autónoma que está naciendo, quedaría libre para replegarse completamente a su lengua literaria propia y preservarla, de este modo, contra toda contaminación. Consideraría, así, productos espurios las versiones de su obra en otras lenguas, y, sobre todo, eludiría la siempre comprometida cuestión del estilo personal, que quedaría reservada a su parroquia vernácula.

La segunda vía, en el otro extremo, consistiría en una reconsideración del propio estilo en la lengua original para adaptarlo a las exigencias de la lengua de traducción, particularmente si ésta es de mayor ámbito. En el caso de ejercer esta opción, probablemente más comercial que literaria, sería legítimo dudar, al cabo de no mucho tiempo, a qué versión de la obra del escritor cabe atribuir la consideración de "original".

Ambas opciones pueden ser ineditadas sin mayores disturbios anímicos, pues llevan implícito un mayor o menor grado de mimetismo clientelista, fácilmente resoluble mediante sencillos cálculos de interés.

Sin embargo, muy otra ha sido la alternativa que ha llevado a nuestro escritor a desfogar su inquietud bajo la lluvia de esta tarde a orillas del mar: el diálogo entre las versiones de una obra - al menos, entre aquellas que resulten decodificables para el propio escritor- puede resolverse en una dinámica permanente de construcción y reconstrucción. Los recursos inherentes a la lengua propia - con mayor razón, si cabe, en el caso de las lenguas minorizadasconstituyen el principal sostén estilístico de la obra original, pero el escritor debe ser, él mismo, permeable a las aportaciones que sea capaz de recibir desde otras esferas estilísticas. En definitiva, la voz propia que siempre persigue el autor es el resultado del traslado a su propio idioma de todo su bagaje literario, adquirido casi siempre en más de una lengua.

La formulación de Steiner, creo que cierta desde el punto de vista del traductor, me parece igualmente valiosa para el escritor: su espejo propio debe estar ajustado a ese conjunto de espejos que llamamos literatura universal, igual que el del traductor a la obra original. Sólo así será posible que la luz mutuamente reflejada se multiplique sin distorsión.

Sigue lloviendo sobre el paraguas del escritor en su camino de vuelta a casa, pero ahora pasea. Tal vez mañana tengamos la traducción en paz. 